\title{
DETERMINAN NIAT PENGAJUAN PEMBIAYAAN MUDHARABAH PADA BMT NURUL JANNAH GRESIK [1]
}

\author{
Friska Mega Puspitasari \\ Mahasiswa Program Studi S1 Ekonomi Islam-Fakultas Ekonomi dan Bisnis-Universitas Airlangga \\ Email : friskamega94@gmail.com
}

Moh. Qudzi Fauzi

Dosen Departemen Ekonomi Syariah-Fakultas Ekonomi dan Bisnis-Universitas Airlangga Email : qudzifauzy1@gmail.com

\begin{abstract}
This study aims to determine the effect of collateral flexibility, quality of service, and sharia compliance on intention of filing of mudharabah financing at BMT Nurul Jannah Gresik. This study used quantitative method and sample used is some community members who reside around BMT Nurul Jannah Gresik. Sampling technique used is purposive sampling. Analysis technique used is multiple linear regression analysis. Results showed that variable of collateral flexibility, quality of service, and sharia compliance both simultaneously and partially has significant effect on intention of filing of mudharabah financing at BMT Nurul Jannah Gresik. Percentage of contributions of the three variables on the intention of filing of mudharabah financing amounted to $62 \%$ and the balance of $38 \%$ influenced by other factors which is not included in this study.
\end{abstract}

Keywords : Collateral Flexibility, Quality of Service, Sharia Compliance, BMT

\section{PENDAHULUAN}

Islam adalah agama rahmatan lil alamin yang membawa perubahan di berbagai bidang, termasuk di bidang ekonomi. Islam sangat memperhatikan dari atau bagaimana harta (hasil kegiatan ekonomi) itu diperoleh dan untuk apa harta itu digunakan. Ekonomi Islam bertujuan mewujudkan tingkat pertumbuhan ekonomi jangka panjang dan memaksimalkan kesejahteraan manusia. Sistem ekonomi syariah hadir dan diharapkan mampu mewujudkan kesejahteraan ekonomi dan keadilan sosial dengan menggunakan sistem bagi hasil.

Lembaga Keuangan Mikro Syariah merupakan institusi yang menyediakan jasa-jasa keuangan kepada penduduk yang berpendapatan rendah dan masyarakat yang termasuk kelompok miskin yang berdasarkan prinsip syariah (Awami, 2009:3). Lembaga keuangan mikro syariah telah menjadi alat yang penting dalam menanggulangi kemiskinan dan membantu pembangunan melalui pengembangan kapasitas bagi masyarakat miskin untuk menikmati kemandirian yang lebih besar dan keberlanjutan dengan memberikan mereka akses ke jasa keuangan (Puskopsyah,2014). Lembaga keuangan mikro syariah adalah bentukan lain dari bank atau sejenisnya yang mempunyai capital kecil dan diperuntukkan untuk sektor usaha mikro kecil. Dalam pengertian ini yang dikategorikan ke dalamnya adalah Baitul Maal Wattamwil, Koperasi Syariah, dan Bank Prekreditan Rakyat Syariah. 
Puspitasari, et al/Jurnal Ekonomi Syariah Teori dan Terapan Vol. 5 No. 1 Januari 2018: 1-16; DETERMINAN NIAT PENGAJUAN PEMBIAYAAN MUDHARABAH PADA BMT NURUL JANNAH GRESIK

Berita yang dimuat dalam

produk pembiayaan gordhul hasan republika.co.id (www.republika.co.id, diakses pada hari Sabtu, 26 Oktober 2013) mengenai Singapura Apresiasi Kiprah BMT di Indonesia, Andrew White sebagai Director International Islamic Law and Finance Centre Singapore Management University (2013) menilai Indonesia sebagai negara pemimpin dalam pengaplikasian Lembaga Kevangan Mikro Syariah (LKMS) atau yang dikenal dengan Baitul Maal Wattamwil (BMT). Dalam definisi operasional PINBUK, BMT adalah lembaga usaha ekonomi rakyat kecil, yang beranggotakan orang seorang atau badan hukum berdasarkan prinsip syariat dan prinsip koperasi (Azra, 2003:237-238).

IImi (2002:2) menjelaskan bahwa lahirnya lembaga keuangan syariah termasuk "Baitul Maal Wattamwil" yang biasa disebut BMT sesungguhnya dilatarbelakangi oleh pelarangan riba secara tegas dalam Al-Qur'an. Sebagian besar umat Islam yang hati-hati dalam menjalankan perintah dan ajaran agamanya menolak menjalin hubungan bisnis dengan perbankan konvensial yang beroperasi dengan sistem bunga. Realita tersebut merupakan faktor penting yang melatarbelakangi lahirnya lembaga keuangan syariah seperti BMT.

Fungsi Baitul Maal pada BMT, berupaya menghimpun dana dari anggota masyarakat yang berupa zakat, infaq, dan shodaqoh dan disalurkan kembali kepada pihak yang berhak menerimanya ataupun dipinjamkan kepada anggota yang benar-benar membutuhkan melalui

(pinjaman dengan bunga nol persen). Sementara Baitut Tamwil, berupaya menghimpun dana masyarakat yang berupa simpanan pokok, simpanan wajib, sukarela dan simpanan berjangka serta penyertaan pihak lain, yang sifatnya merupakan kewajiban BMT untuk mengembalikannya. Dana yang terhimpun diputar secara produktif bisnis kepada para anggotanya dengan pola syariah (Noviandi, 2009:25).

BMT merupakan lembaga non perbankan yang menggunakan syari'at Islam dan berbadan hukum koperasi. Secara kelembagaan BMT didampingi atau didukung oleh Pusat Inkubasi Bisnis Usaha Kecil (PINBUK). PINBUK merupakan lembaga primer karena mengemban misi yang lebih luas, yakni menetaskan usaha kecil. Keberadaan BMT merupakan representasi dari kehidupan masyarakat dimana BMT mampu mengakomodir kepentingan ekonomi masyarakat. Peran umum BMT adalah melakukan pembinaan dan pendanaan yang berdasarkan sistem syari'ah, hal ini sangat penting karena bersentuhan langsung dengan kehidupan ekonomi masyarakat kecil.

BMT Nurul Jannah merupakan salah satu BMT yang sedang berkembang di Kabupaten Gresik, yang awalnya merupakan bagian dari Seksi Mental Spiritual Islam (SMSI) atau sekarang disebut Seksi Bina Rohani Islam (SBRI) PT. Petrokimia Gresik. BMT Nurul Jannah mendapatkan akta pendirian dari Departemen Koperasi Pengusaha Kecil dan Menengah 
Puspitasari, et al/Jurnal Ekonomi Syariah Teori dan Terapan Vol. 5 No. 1 Januari 2018: 1-16; DETERMINAN NIAT PENGAJUAN PEMBIAYAAN MUDHARABAH PADA BMT NURUL JANNAH GRESIK

Kabupaten Gresik dengan No. pengembangan produknya, BMT Nurul 489/BH/KWK.13/VII/98 dengan nama Koperasi Baitul Maal Wattamwil Nurul Jannah. Selain itu dengan dikeluarkannya Undang-Undang Pengelolaan Zakat No. 38 tahun 1999 dan peraturan pelaksanaannya dengan Keputusan Menteri Agama Republik Indonesia No. 581 tahun 1999, maka Koperasi BMT Nurul Jannah telah mendapatkan Surat Keputusan dari Bupati Gresik No.450/3436/HK/403.14/2002 tentang pengukuhan Koperasi BMT Nurul Jannah sebagai Lembaga Amil Zakat (LAZ).

Program kerja yang dikembangkan oleh BMT Nurul Jannah Gresik ada dua yang pertama yakni divisi maal yang diprioritaskan pada beberapa program kerja yaitu bina sosial, bina pendidikan, bina masjid atau pondok, bina dakwah serta asnaf lain. Yang kedua yakni divisi tamwil dimana BMT Nurul Jannah Gresik melakukan penggalangan dana melalui masyarakat terutama karyawan PT. Petrokimia Gresik, menyalurkan dana kepada pengusaha-pengusaha mikro muslim untuk memberikan pembiayaan (kredit usaha) dengan pola syariah, serta melakukan pembinaan baik berupa mental spiritual Islam maupun pembinaan manajemen usaha.

Adapun produk-produk dari BMT Nurul Jannah Gresik dibagi menjadi dua, produk tabungan (tabungan mudharabah, tabungan pendidikan, tabungan qurban, dan tabungan haji) dan produk pembiayaan (pembiayaan mudharabah dan pembiayaan murabahah). Dalam 
Puspitasari, et al/Jurnal Ekonomi Syariah Teori dan Terapan Vol. 5 No. 1 Januari 2018: 1-16; DETERMINAN NIAT PENGAJUAN PEMBIAYAAN MUDHARABAH PADA BMT NURUL JANNAH GRESIK

masih sangat membutuhkan pembiayaan sebagai tambahan dana baik untuk modal usaha, konsumsi, investasi maupun membeli barang-barang yang dibutuhkan, maka keberadaan BMT Nurul Jannah Gresik sangat membantu masyarakat. Lembaga keuangan berbasis syariah ini diharapkan bisa menjadi pilihan utama masyarakat Indonesia khususnya masyarakat Gresik sendiri yang sebagian besar beragama Islam. Karena BMT selain mampu menjangkau masyarakat menengah ke bawah yang membutuhkan pinjaman, BMT juga bebas dari bunga.

Hingga saat ini BMT belum melakukan evaluasi terkait pengajuan pembiayaan khususnya pembiayaan mudharabah. Kajian terkait pengajuan pembiayaan mudharabah menjadi penting bagi pengelola BMT untuk dapat memahami determinan niat pengajuan pembiayaan sekaligus untuk memperbaiki kinerja BMT dalam melayani masyarakat, khususnya warga Gresik yang diberdayakan oleh BMT. Berdasarkan kajian literatur, peneliti menemukan sejumlah determinasi yang mempengaruhi niat nasabah untuk mengajukan pembiayaan khususnya pembiayaan mudharabah pada BMT Nurul Jannah Gresik yaitu antara lain fleksibilitas jaminan, kualitas pelayanan, dan kepatuhan syariah.

Determinan pertama yang terkait dengan niat pengajuan pembiayaan mudharabah yaitu fleksibilitas jaminan. Sutarno (2004:94) menyatakan bahwa jaminan merupakan satu dari 5 faktor yang dipertimbangkan oleh lembaga keuangan untuk mengetahui atau menentukan seorang calon nasabah dipercaya untuk memperoleh pembiayaan. Fleksibilitas jaminan dalam Lembaga Kevangan Syariah dicerminkan dalam prinsip dasarnya yakni tidak mengharuskan calon nasabah untuk memberikan jaminan dalam pengajuan pembiayaan dalam bentuk apapun, dengan kata lain transaksi peminjaman biaya melalui Lembaga Keuangan Syariah dapat dilandaskan pada kepercayaan.

Determinan kedua adalah kualitas pelayanan BMT. Parasuman dan Pujawan (1997) yang dikutip dalam Mauludin (2004) mengemukakan bahwa kualitas pelayanan merupakan ukuran penilaian menyeluruh atas tingkat suatu pelayanan yang baik. Dalam penelitian Arslan (2014) menunjukkan bahwa kualitas pelayanan berpengaruh secara positif pada niat pembelian.

Determinan terakhir adalah kepatuhan syariah. Makna kepatuhan syariah menurut Prasetyo (2005:59) dalam Sutedi (2009:145) adalah kepatuhan Lembaga Kevangan Syariah kepada fatwa DSN (Dewan Syariah Nasional), karena fatwa DSN merupakan perwujudan prinsip dan aturan syariah yang harus ditaati dalam perbankan syariah maupun lembaga keuangan syariah non bank di Indonesia. Dalam penelitian Murningsih dan Yunadi (2013) mengatakan bahwa faktor syariah berpengaruh positif dan signifikan terhadap permintaan pembiayaan mudharabah. 
Puspitasari, et al/Jurnal Ekonomi Syariah Teori dan Terapan Vol. 5 No. 1 Januari 2018: 1-16; DETERMINAN NIAT PENGAJUAN PEMBIAYAAN MUDHARABAH PADA BMT NURUL JANNAH GRESIK

Berdasarkan latar belakang di atas, maka rumusan masalah dalam penelitian ini adalah :

1. Apakah fleksibilitas jaminan, kualitas pelayanan, dan kepatuhan syariah secara simultan berpengaruh terhadap niat pengajuan pembiayaan mudharabah pada BMT Nurul Jannah Gresik?

2. Apakah fleksibilitas jaminan berpengaruh terhadap niat pengajuan pembiayaan mudharabah pada BMT Nurul Jannah Gresik?

3. Apakah kualitas pelayanan berpengaruh terhadap niat pengajuan pembiayaan mudharabah pada BMT Nurul Jannah Gresik?

4. Apakah kepatuhan syariah berpengaruh terhadap niat pengajuan pembiayaan mudharabah pada BMT Nurul Jannah Gresik?

Adapun tujuan dari penelitian ini adalah untuk mengetahui pengaruh fleksibilitas jaminan, kualitas pelayanan, dan kepatuhan syariah baik secara parsial maupun simultan terhadap niat pengajuan pembiayaan mudharabah pada BMT Nurul Jannah Gresik

\section{LANDASAN TEORI DAN PENGEMBANGAN HIPOTESIS}

\section{Baitul Maal Wattamwil}

Baitul Maal Wattamwil (BMT) terdiri dari dua istilah, yaitu Baitul Maal dan Baitut Tamwil. Baitul Maal lebih mengarah pada usaha-usaha pengumpulandan penyaluran dana yang non-profit, seperti; zakat, infaq, shodaqoh. Sedangkan Baitut Tamwil sebagai usaha pengumpulan dan penyaluran dana komersial" (Sudarsono, 2003:103).

Menurut Huda dan Heykal (2010:364) fungsi BMT bagi masyarakat, adalah :

1. Dapat meningkatkan kualitas Sumber Daya Manusia pihak-pihak yang terkait, seperti anggota, pengurus, pengelola menjadi lebih profesional.

2. Mengorganisasi dana sehingga dana yang dimiliki masyarakat dapat termanfaatkan secara optimal di dalam maupun luar organisasi untuk kepentingan rakyat banyak.

3. Mengembangkan kesempatan kerja sehingga dapat mengurangi jumlah pengangguran.

4. Mengukuhkan dan meningkatkan kualitas usaha dan pasar produkproduk anggota. Memperkuat dan meningkatkan kualitas lembagalembaga ekonomi dan sosial masyarakat banyak.

\section{Pembiayaan Mudharabah}

Pembiayaan mudharabah merupakan akad kerjasama dua orang atau lebih dimana salah satu pihak bertindak sebagai penyedia modal secara penuh (shohibul maal) dan pihak lain bertindak sebagai yang menjalankan usaha (mudharib) dimana pembagian keuntungan sesuai dengan kesepakatan bersama di awal akad, sedangkan kerugian ditanggung oleh pemilik dana tetapi bila kerugian disebabkan oleh pengelola dana maka pengelola dana 
Puspitasari, et al/Jurnal Ekonomi Syariah Teori dan Terapan Vol. 5 No. 1 Januari 2018: 1-16; DETERMINAN NIAT PENGAJUAN PEMBIAYAAN MUDHARABAH PADA BMT NURUL JANNAH GRESIK

yang harus menanggungnya (Ridwan,

Behavior dan model Health related 2004:96).

Umumnya porsi bagi hasil ditetapkan bagi mudharib lebih besar daripada shahibul maal, pada akhirnya jangka waktu pembiayaan, dana pembiayaan dikembalikan kepada pihak shahibul maal. Pada pembiayaan mudharabah pihak shahibul maal tidak boleh ikut serta dalam manajemen proyek yang dibiayai (Perwataatmadja dan Tanjung, 2007:77).

Landasan hukum terkait dengan pembiayaan mudharabah terdapat dalam firman Allah surat An-Nisa ayat 29.

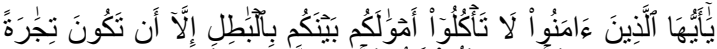

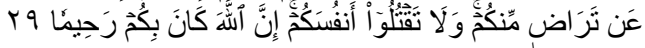

yÉ-'ayyuha'l-ladi̇Êna ÉmanË lÉ ta'kulË- amwÉ lakum baynakum bi'l-bÉ ÏIili i'l-lÉ- an takË na tijÉ rotan 'antarÉ- İin minkum walÉ taqtulËanfusakum inna'l-LÉha kÉna bikum roÍlEmÉ

Artinya: "Hai orang-orang yang beriman, janganlah kamu saling memakan harta sesamamu dengan jalan yang batil, kecuali dengan jalan perniagaan yang berlaku dengan suka sama-suka di antara kamu. Dan janganlah kamu membunuh dirimu; Sesungguhnya Allah adalah Maha Penyayang kepadamu." (QS 4:29, Departemen Agama Rl, 1998:122).

\section{Niat}

Niat adalah instruksi yang diberikan seseorang untuk dirinya sendiri dengan cara tertentu. Niat merupakan keputusan seseorang untuk melakukan tindakan tertentu. Dalam istilah psikologi, niat menunjukkan motivasi seseorang untuk menunjukkan suatu perilaku. Oleh karena itu niat dapat menunjukkan arah keputusan (untuk melakukan $X$ atau untuk tidak melakukan $X$ ). Niat menjadi poin terpenting dari Theories of Attitudebehavior. Menurut Theory of reasoned action, niat adalah prediktor perilaku dan sebagai penengah dari variabel lain misalnya sikap atau norma subjektif pada perilaku. Teori of planned behavior juga mengasumsikan bahwa niat adalah prediktor yang paling penting dari perilaku tetapi perlu diketahui bahwa orang mungkin tidak selalu memiliki kontrol yang cukup untuk melakukan perilaku yang benar-benar melaksanakan niat mereka (Ajzen, 1985, 1991) dalam Sheeran (2011).

Dalam Islam, niat diartikan sebagai salah satu pokok seseorang hendak melakukan sesuatu. Seseorang akan mendapatkan suatu ganjaran pahala atas dosa itu sesuai dengan niatnya. Seperti halnya hadits yang diriwayatkan oleh Imam Bukhari.

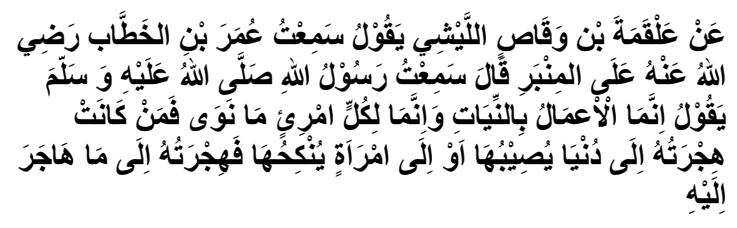

'an 'alqamata-bni waqāṣillaysyi yaqūlu sami'tu 'umara-bnil-khațtaabi radliyallahu anhu alalminbari qāla sami'tu Rasulullāhi șollallahu 'alaihi wasallama yaquulu. Innamā-la'malu binniyāti wainnamā likullimriim mānawa faman kānat hijratuhu ila dunyā yușībuhā aw ilamra-atiyyunkihuhā fahijratahu ila mā hājara ilayhi

Dari 'Alqamah bin Waqqash Al-Laitsi bahwa ia berkata, "Aku mendengar Umar bin Khatthab RA berkata di atas mimbar, AkU mendengar Rasulullah SAW bersabda, "Tiap-tiap amal perbuatan harus disertai dengan niat, balasan bagi setiap amal manusia sesuai dengan apa yang diniatkan. Barangsiapa yang berhijrah untuk mengharapkan dunia atau seorang perempuan untuk dinikahi, maka hijrahnya sesuai dengan apa yang diniatkan." (Ummah, 2002:17-18). 
Puspitasari, et al/Jurnal Ekonomi Syariah Teori dan Terapan Vol. 5 No. 1 Januari 2018: 1-16; DETERMINAN NIAT PENGAJUAN PEMBIAYAAN MUDHARABAH PADA BMT NURUL JANNAH GRESIK

Hadits di atas menjelaskan bahwasanya semua itu tergantung dan sesuai dengan apa yang jadi niat masingmasing. Ibnu Abbas pernah berkata bahwa "Sesungguhnya seseorang hanya dipelihara oleh Allah sesuai dengan kadar niatnya". Sahabat lain mengatakan pula bahwa sesungguhnya manusia itu hanya diberi sesuai dengan kadar niatnya masing-masing (An-Nawawi, 2007:8), akan tetapi dalam melakukan sesuatu harus diiringi dengan keikhlasan, karena keikhlasan seseorang itulah yang akan sampai kepada Allah. Penjelasan tersebut menunjukkan betapa pentingnya niat dalam sudut pandang Islam.

Determinasi yang Mempengaruhi Niat Pengajuan Pembiayaan Mudharabah

Menurut Kasmir (2004:91) collateral merupakan jaminan yang diberikan calon nasabah baik yang bersifat fisik maupun non fisik. Fleksibilitas memegang peranan penting dalam berbagai analisis kevangan, misalnya dalam fleksibilitas keuangan nasabah dan fleksibilitas jaminan keuangan (Rosmalinda, 2015). Fleksibilitas jaminan dalam Lembaga Kevangan Syariah dicerminkan dalam prinsip dasarnya yakni tidak mengharuskan calon nasabah untuk memberikan jaminan dalam pengajuan pembiayaan dalam bentuk apapun, dengan kata lain transaksi peminjaman biaya melalui Lembaga Keuangan Syariah dapat dilandaskan pada kepercayaan. Hal ini sesuai dengan fatwa Dewan Syariah Nasional No: 07/DSN-MUI/IV/2000 yang bunyinya Lembaga Keuangan
Syariah boleh mensyaratkan adanya jaminan agar mudharib tidak melakukan penyimpangan, namun tidak terdapat aturan yang baku sebagaimana diterapkan pada Lembaga Keuangan Konvensional yang mensyaratkan jaminan bernilai sama atau melebihi plafon kredit yang diajukan nasabah.

Parasuraman, et al., mendefinisikan kualitas pelayanan sebagai perbandingan antara layanan yang diharapkan konsumen dengan layanan yang diterimanya. Kualitas pelayanan merupakan ukuran penilaian menyeluruh atas tingkat suatu pelayanan yang baik.

Prasetyo (2005:59) dalam Sutedi (2009:145) menjelaskan makna kepatuhan syariah secara operasional (praktis) adalah kepatuhan kepada fatwa DSN (Dewan Syariah Nasional), karena fatwa DSN merupakan perwujudan prinsip dan aturan syariah yang harus ditaati dalam perbankan syariah maupun lembaga keuangan syari'ah non bank di Indonesia.

\section{Hipotesis}

$\mathrm{H}_{1}$ : Fleksibilitas jaminan, kualitas pelayanan, dan kepatuhan syariah secara simultan berpengaruh signifikan terhadap niat pengajuan pembiayaan mudharabah pada BMT Nurul Jannah Gresik.

$\mathrm{H}_{2}$ : Fleksibilitas jaminan berpengaruh signifikan terhadap niat pengajuan pembiayaan mudharabah pada BMT Nurul Jannah Gresik.

$\mathrm{H}_{3}$ : Kualitas pelayanan berpengaruh signifikan terhadap niat pengajuan 
Puspitasari, et al/Jurnal Ekonomi Syariah Teori dan Terapan Vol. 5 No. 1 Januari 2018: 1-16; DETERMINAN NIAT PENGAJUAN PEMBIAYAAN MUDHARABAH PADA BMT NURUL JANNAH GRESIK

pembiayaan mudharabah pada BMT

Nurul Jannah Gresik.

$\mathrm{H}_{4}$ : Kepatuhan syariah berpengaruh signifikan terhadap niat pengajuan pembiayaan mudharabah pada BMT Nurul Jannah Gresik.

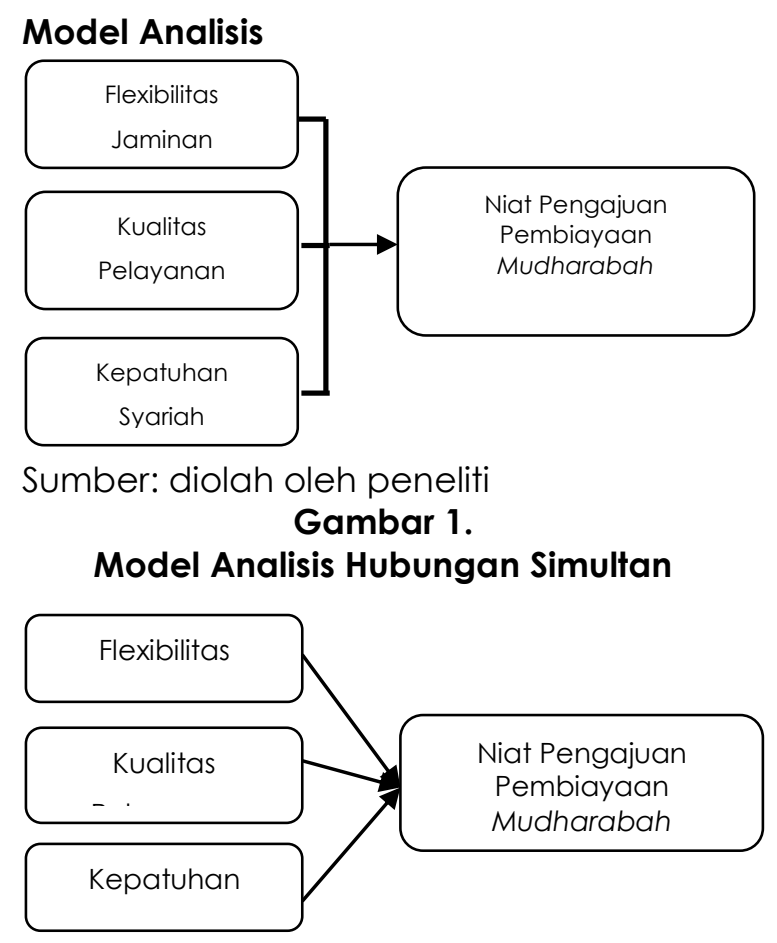

Sumber: diolah oleh peneliti

Gambar 2.

Model Analisis Hubungan Parsial

\section{METODE PENELITIAN}

Pendekatan yang digunakan dalam penelitiaan ini adalah pendekatan kuantitatif dengan metode regresi linear berganda.

\section{Definisi Operasional Variabel \\ Fleksibilitas Jaminan $\left(\mathrm{X}_{1}\right)$}

Fleksibilitas menurut Oxford Dictionary didefinisikan sebagai kemampuan untuk dapat dengan mudah dimodifikasi atau keinginan untuk merubah atau mengkompromikan suatu keadaan. Menurut Kasmir (2004:91) Collateral merupakan jaminan yang diberikan calon 
Puspitasari, et al/Jurnal Ekonomi Syariah Teori dan Terapan Vol. 5 No. 1 Januari 2018: 1-16; DETERMINAN NIAT PENGAJUAN PEMBIAYAAN MUDHARABAH PADA BMT NURUL JANNAH

\section{GRESIK}

adapun indikator-indikator tersebut

adalah sebagai berikut :

a. Adanya fasilitas fisik seperti kebersihan ruangan kantor BMT.

b. Pengurus BMT menunjukkan komunikasi yang baik sebagai bentuk perhatian kepada para nasabah.

c. Pengurus BMT mampu memberikan pelayanan sesuai yang dijanjikan dan konsisten kepada nasabah.

d. Keinginan dari pegawai BMT untuk membantu para nasabah dan memberikan pelayanan dengan cepat.

e. Pengetahuan dan sifat dapat dipercaya yang dimiliki pengurus BMT.

\section{Kepatuhan Syariah $\left(\mathrm{X}_{3}\right)$}

Prasetyo (2005:59) dalam Sutedi (2009:145) menjelaskan makna kepatuhan syariah adalah kepatuhan kepada fatwa DSN, karena fatwa DSN merupakan perwujudan prinsip dan aturan syariah yang harus ditaati dalam perbankan syariah maupun lembaga keuangan syari'ah non bank di Indonesia. Kepatuhan syariah yang dimaksud dalam penelitian ini adalah pengetahuan masyarakat atau calon mudharib terhadap kepatuhan pemenuhan prinsipprinsip syariah dalam kegiatan yang dilakukan oleh BMT Nurul Jannah Gresik. Menurut Sutedi (2009:146) indikator kepatuhan syariah sebagai berikut :

a. Akad sesuai dengan syariah

b. Budaya perusahaan sesuai dengan syariah c. Usaha yang dibiayai sesuai dengan syariah

d. Sumber dana yang diperoleh halal sesuai dengan syariah

\section{Niat Pengajuan Pembiayaan Mudharabah}

(Y)

Niat pengajuan pembiayaan mudharabah adalah niat calon mudharib untuk mengajukan pembiayaan dalam jumlah tertentu kepada BMT Nurul Jannah Gresik untuk menjalankan kegiatan usahanya. Pengajuan pembiayaan mudharabah diukur dengan kuatnya niat calon mudharib untuk mengajukan pembiayaan mudharabah kepada BMT Nurul Jannah Gresik. Indikator niat pengajuan pembiayaan mudharabah antara lain (Agag, 2016) :

a. Berniat mengajukan pembiayaan mudharabah (modal usaha) dalam waktu dekat.

b. Memiliki keinginan untuk memperoleh biaya pengembangan usaha dalam waktu dekat.

c. Jika membutuhkan modal usaha, calon nasabah akan menghubungi lembaga keuangan untuk mendapatkannya.

\section{Jenis dan Sumber Data}

Data primer diperoleh dari kuesioner, sedangkan data sekunder diperoleh dari dokumen kerja yang diperoleh dari BMT Nurul Jannah Gresik serta studi pustaka mengkaji buku-buku, jurnal, makalah, dan sumber-sumber lain yang berkaitan dengan penelitian.

\section{Populasi dan Sampel Penelitian}


Puspitasari, et al/Jurnal Ekonomi Syariah Teori dan Terapan Vol. 5 No. 1 Januari 2018: 1-16; DETERMINAN NIAT PENGAJUAN PEMBIAYAAN MUDHARABAH PADA BMT NURUL JANNAH GRESIK

Populasi dalam penelitian ini adalah masyarakat Gresik yang bertempat tinggal disekitar BMT Nurul Jannah Gresik. Sampel dalam penelitian ini sebanyak 97 responden yang ditentukan dengan perhitungan populasi infinit. Sampel dipilih menggunakan teknik Sampling Purposive, dengan kriteria sebagai berikut :

1. Bertempat tinggal di sekitar BMT Nurul Jannah Gresik.

2. Mengetahui adanya BMT Nurul Jannah Gresik.

3. Memiliki keinginan untuk memulai atau megembangkan usaha dalam waktu dekat.

\section{Teknik Analisis Data}

Uji Validitas dan Uji Reliabilitas Instrumen

Uji validitas dalam penelitian ini dilakukan dengan melakukan korelasi bivariate antara masing-masing skor indikator dengan total skor konstruk dengan menggunakan uji Pearson Product Moment, dimana sebuah indikator dikatakan valid jika nilai koefisen Pearson Product Moment nya $\geq 0,3$ (Ghozali, 2012:52).

Uji reliabilitas dalam penelitian ini menggunakan teknik Cronbach's Alpha, yakni menghitung koefisien alpha. Menurut Nunally (1994) dalam Ghozali (2012:48) menyatakan bahwa suatu konstruk atau variabel dikatakan reliabel jika memberikan nilai Cronbach's Alpha > 0,7 .

\section{Uji Asumsi Klasik}

Uji Linearitas
Menurut Ghozali (2012:166) uji linearitas digunakan untuk melihat apakah spesifikasi model yang digunakan sudah benar atau tidak. Data penelitian dikatakan mengikuti kurva linier jika nilai Sig. pada baris Linearity $<0,05$ pada taraf kesalahan penelitian sebesar $5 \%$.

\section{Uji Normalitas}

Pada penelitian ini uji normalitas dilakukan dengan menggunakan metode Kolmogorov Smirnov maupun pendekatan grafik Normal P-P Plot of regression standard. Menurut Santoso (2011: 214) data berdistribusi normal apabila nilai probabilitas $\geq 0,05$ serta jika penyebaran data (titik) disekitar sumbu diagonal dan mengikuti arah garis diagonal, maka model regresi memenuhi asumsi normalitas.

\section{Uji Multikolinieritas}

Uji gejala multikolinearitas digunakan untuk menguji apakah model regresi ditemukan adanya korelasi antar variabel bebas (Gozali, 2012:105). Untuk mendeteksi ada tidaknya gejala multikolinearitas digunakan indikasi nilai Variance Inflation Factor (VIF). Terjadi kondisi multikolinieritas jika nilai VIF > 10.

\section{Uji Heterokedastisitas}

Uji heterokedastisitas bertujuan menguji apakah model regresi terjadi ketidaksamaan variance dari residual satu pengamatan ke pengamatan lain (Ghozali, 2012:139). Uji gejala heterokedastisitas depat diketahui dengan menggunakan grafik plot (scatter plot). Jika titik-titik menyebar dan tidak membentuk pola yang khas maka uji 
Puspitasari, et al/Jurnal Ekonomi Syariah Teori dan Terapan Vol. 5 No. 1 Januari 2018: 1-16; DETERMINAN NIAT PENGAJUAN PEMBIAYAAN MUDHARABAH PADA BMT NURUL JANNAH GRESIK

regresi tidak terkena asumsi heterokedastisitas.

\section{Regresi Linier Berganda}

Menurut Ghozali (2012:96) dalam analisis regresi, selain mengukur kekuatan antara dua variabel atau lebih, juga menujukkan arah hubungan antara variabel depanden dengan vaiabel independen. Regresi linear berganda diformulasikan sebagai berikut :

$Y=a+\beta_{1} X_{1}+\beta_{2} X_{2}+\beta_{3} X_{3}+e_{i}$

Keterangan :

Y : Niat Pengajuan Pembiayaan Mudharabah

$\mathrm{X}_{1}$ : Fleksibilitas Jaminan

$\mathrm{X}_{2}$ : Kualitas Pelayanan

$\mathrm{X}_{3}$ : Kepatuhan Syariah

$\beta_{1} \beta_{2} \beta_{3}$ : Koefisien Regresi

$a:$ Intercept

$e_{i}$ : Variabel Pengganggu

Uji Statistik F

Uji $F$ digunakan untuk menujukkan apakah semua variabel independen yang dimasukkan dalam model mempunyai pengaruh secara bersama-sama terhadap variabel dependen (Ghozali, 2012:98). Pengambilan keputusan uji $F$ dilakukan dengan melihat nilai probabilitas, jika nilai probabilitas $<0,05$ maka variabel independen secara simultan signifikan atau mempunyai pengaruh terhadap variabel dependen, maka $\mathrm{H}_{0}$ ditolak $\mathrm{HA}$ diterima.

\section{Uji Statistik}

Uji $†$ digunakan untuk menunjukkan seberapa jauh pengaruh satu variabel independen secara individual dalam menerangkan variasi variabel dependen

(Ghozali, 2012:98). Pengambilan keputusan uji $\dagger$ dilakukan dengan melihat nilai probabilitas, jika nilai probabilitas < 0,05 maka variabel independen secara individu signifikan atau mempunyai pengaruh terhadap variabel dependen, maka $\mathrm{H}_{\mathrm{o}}$ ditolak HA diterima.

\section{Koefisien Determinasi}

Nilai koefisien determinasi menggambarkan seberapa besar variasi dari variabel independen dapat dijelaskan oleh variabel dependennya.

III. HASIL DAN PEMBAHASAN

Uji Validitas

Tabel 1.

Hasil Uji Validitas Variabel Penelitian

\begin{tabular}{|c|c|c|c|c|}
\hline Variabel & Indikator & $\begin{array}{c}\text { Pearson } \\
\text { Correlatio } \\
n\end{array}$ & Batas & $\begin{array}{c}\text { Keteranga } \\
\mathbf{n}\end{array}$ \\
\hline \multirow{3}{*}{$\begin{array}{c}\text { Fleksibilitas } \\
\text { Jaminan }\end{array}$} & FJ1 & 0,901 & \multirow{12}{*}{$\geq 0,3$} & Valid \\
\hline & FJ2 & 0,877 & & Valid \\
\hline & FJ3 & 0,844 & & Valid \\
\hline \multirow{5}{*}{$\begin{array}{c}\text { Kualitas } \\
\text { Pelayanan }\end{array}$} & KPl & 0,725 & & Valid \\
\hline & KP2 & 0,787 & & Valid \\
\hline & KP3 & 0,690 & & Valid \\
\hline & KP4 & 0,803 & & Valid \\
\hline & KP5 & 0,800 & & Valid \\
\hline \multirow{4}{*}{$\begin{array}{l}\text { Kepatuhan } \\
\text { Syariah }\end{array}$} & KSI & 0,863 & & Valid \\
\hline & KS2 & 0,831 & & Valid \\
\hline & KS3 & 0,727 & & Valid \\
\hline & KS4 & 0,785 & & Valid \\
\hline
\end{tabular}

Lanjutan Tabel 1.

\begin{tabular}{|c|c|c|c|c|}
\hline Variabel & Indikator & $\begin{array}{c}\text { Pearson } \\
\text { Correlation }\end{array}$ & \multirow{2}{*}{ Batas } & Keterangan \\
\hline \multirow{2}{*}{$\begin{array}{c}\text { Niat } \\
\text { Pengajuan }\end{array}$} & NP1 & 0,857 & & Valid \\
\cline { 2 - 3 } $\begin{array}{c}\text { Pembiayaan } \\
\text { Mudharabah }\end{array}$ & NP2 & 0,830 & Valid \\
\cline { 2 - 3 } & NP3 & 0,875 & & Valid \\
\hline
\end{tabular}

Sumber : Data olahan SPSS Statistics version 18

Tabel 1. menunjukkan bahwa seluruh indikator pada variabel dalam penelitian ini merupakan indikator yang valid karena memiliki nilai Pearson Correlation $\geq 0,3$. Atas dasar tersebut maka seluruh indikator memenuhi syarat validitas dan akan tetap 
Puspitasari, et al/Jurnal Ekonomi Syariah Teori dan Terapan Vol. 5 No. 1 Januari 2018: 1-16; DETERMINAN NIAT PENGAJUAN PEMBIAYAAN MUDHARABAH PADA BMT NURUL JANNAH GRESIK

dipertahankan dalam skala dan dipergunakan dalam analisis selanjutnya.

Uji Reliabilitas

Tabel 2.

Hasil Uji Reliabilitas Variabel Penelitian

\begin{tabular}{|l|c|c|c|}
\hline \multicolumn{1}{|c|}{ Variabel } & $\begin{array}{c}\text { Alpha } \\
\text { Cronbach }\end{array}$ & Batas & Keterangan \\
\hline $\begin{array}{l}\text { Fleksibilitas } \\
\text { Jaminan }\end{array}$ & 0,837 & & Reliabel \\
\hline $\begin{array}{l}\text { Kualitas } \\
\text { Pelayanan }\end{array}$ & 0,818 & \multirow{4}{*}{$>0.70$} & Reliabel \\
\cline { 1 - 2 } $\begin{array}{l}\text { Kepatuhan } \\
\text { Syariah }\end{array}$ & 0,813 & Reliabel \\
\hline $\begin{array}{l}\text { Niat Pengajuan } \\
\text { Pembiayaan } \\
\text { Mudharabah }\end{array}$ & 0,812 & & Reliabel \\
\hline
\end{tabular}

Sumber : Data olahan SPSS Statistics version 18

Berdasarkan Tabel 2. hasil perhitungan

menunjukkan nilai alpha cronbach mempunyai nilai $>0,70$ sehingga seluruh variabel dalam penelitian ini dinyatakan mempunyai reliabilitas yang baik.

Uji Asumsi Klasik

Uji Linearitas

Tabel 3.

Hasil Uji Linearitas

\begin{tabular}{|l|c|c|c|}
\hline $\begin{array}{c}\text { Variabel } \\
\text { Independe } \\
\mathbf{n}\end{array}$ & $\begin{array}{c}\text { Nilai } \\
\text { Linearit } \\
\mathbf{y}\end{array}$ & $\begin{array}{c}\text { Nilai } \\
\text { Deviatio } \\
\mathbf{n} \text { from } \\
\text { Linearity }\end{array}$ & $\begin{array}{c}\text { Keteranga } \\
\mathbf{n}\end{array}$ \\
\hline $\begin{array}{l}\text { Fleksibilitas } \\
\text { Jaminan }\end{array}$ & 0,000 & 0,291 & Linier \\
\hline $\begin{array}{l}\text { Kualitas } \\
\text { Pelayanan }\end{array}$ & 0,000 & 0,009 & Linier \\
\hline $\begin{array}{l}\text { Kepatuhan } \\
\text { Syariah }\end{array}$ & 0,000 & 0,609 & Linier \\
\hline
\end{tabular}

Sumber : Data olahan SPSS Statistics version 18

Berdasarkan tabel di atas dapat diketahui bahwa nilai Linearity untuk semua variabel independen kurang dari 0,05 pada taraf kesalahan sebesar $5 \%$, hal ini menunjukkan bahwa setiap variabel independen memiliki hubungan yang linier dengan niat pengajuan pembiayaan mudharabah.

\section{Uji Normalitas}

\section{Tabel 4.}

Hasil Uji Kolmogorov-Smirnov

\begin{tabular}{|l|c|}
\hline & \multicolumn{1}{|}{$\begin{array}{c}\text { Unstandarized } \\
\text { Residual }\end{array}$} \\
\hline $\begin{array}{l}\text { Kolmogorov- } \\
\text { Smirnov Z Sig. (2- }\end{array}$ & 0,919 \\
\hline $\begin{array}{l}\text { Asymp. Sig. } \\
\text { tailed) }\end{array}$ & 0,368 \\
\hline
\end{tabular}

Sumber : Data olahan SPSS Statistics version 18

Berdasarkan Tabel 4. diperoleh nilai Kolmogrov-Smirnov sebesar 0,919 dengan tingkat signifikansi 0,368 . Nilai signifikansi ini lebih dari 0,05. Hal ini menunjukan bahwa residual data terdistribusi secara normal.

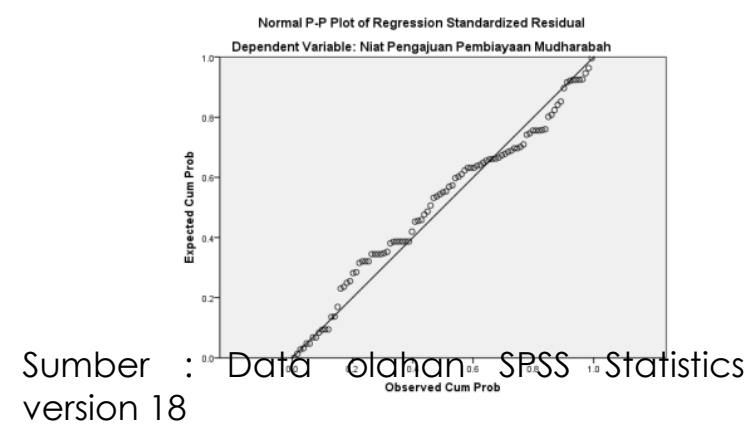

Gambar 3.

Grafik Normalitas P-P Plot

Berdasarkan Gambar 3. terlihat bahwa data menyebar berhimpit di sekitar garis diagonal dan mengikuti arah garis diagonal. Dapat disimpulkan bahwa grafik P-P plot menunjukkan data terdistribusi secara normal.

\section{Uji Multikolinieritas}

Tabel 5.

Uji Gejala Multikolinieritas Variabel bebas

\begin{tabular}{|c|c|c|c|}
\hline \multirow{2}{*}{ Variabel } & \multicolumn{2}{|c|}{$\begin{array}{l}\text { Collineriaty } \\
\text { Statistics }\end{array}$} & \multirow{2}{*}{ Keterangan } \\
\hline & Tolerance & VIF & \\
\hline $\begin{array}{l}\text { Fleksibilitas } \\
\text { Jaminan }\end{array}$ & 0,690 & $\begin{array}{c}1,44 \\
9 \\
\end{array}$ & $\begin{array}{l}\text { Bebas } \\
\text { Multikolinieritas }\end{array}$ \\
\hline $\begin{array}{l}\text { Kualitas } \\
\text { Pelayanan }\end{array}$ & 0,581 & $\begin{array}{c}1,72 \\
2 \\
\end{array}$ & $\begin{array}{l}\text { Bebas } \\
\text { Multikolinieritas }\end{array}$ \\
\hline $\begin{array}{l}\text { Kepatuhan } \\
\text { Syariah }\end{array}$ & 0,493 & $\begin{array}{c}2,02 \\
9\end{array}$ & $\begin{array}{l}\text { Bebas } \\
\text { Multikolinieritas }\end{array}$ \\
\hline
\end{tabular}

Sumber : Data olahan SPSS Statistics version 18

Dalam penelitian ini tidak terjadi multikol atau non multikol karena nilai VIF dari masing-masing variabel fleksibilitas 
Puspitasari, et al/Jurnal Ekonomi Syariah Teori dan Terapan Vol. 5 No. 1 Januari 2018: 1-16; DETERMINAN NIAT PENGAJUAN PEMBIAYAAN MUDHARABAH PADA BMT NURUL JANNAH

\section{GRESIK}

jaminan, kualitas pelayanan, dan kepatuhan syariah kurang dari 10.

Uji Heterokedastisitas

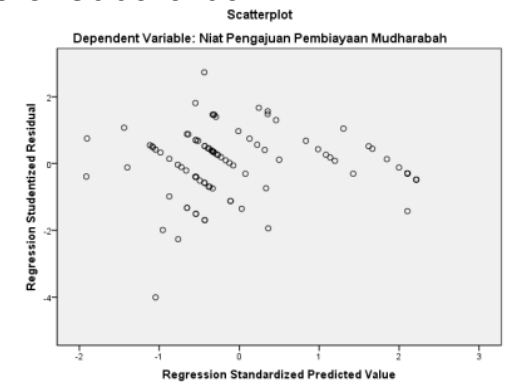

Sumber : Data olahan SPSS Statistics version 18

Gambar 4.

Uji Heterokedastisitas

Berdasarkan Gambar 4. diagram scatterplot diatas menunjukkan bahwa titik-titik menyebar tidak mengumpul dan tidak membentuk pola yang khas. Dengan demikian dapat disimpulkan bahwa terjadi gejala homoskedastisitas atau tidak terjadi hubungan antara variabel dependen dengan variabel independen, sehingga variabel dependen benar-benar hanya dijelaskan oleh variabel independen.

Uji Statistik F

Tabel 6.

Hasil Uji F

\begin{tabular}{|c|l|c|c|}
\hline \multicolumn{2}{|c|}{ Model } & F & Sig. \\
\hline 1 & Regression & 50,532 & 0,000 \\
\hline
\end{tabular}

Sumber : Data olahan SPSS Statistics version 18

Pada Tabel 6. dapat dilihat bahwa hasil pengujian menunjukkan nilai $F$ hitung sebesar 50,532 dengan tingkat signifikansi uji F hitung adalah sebesar 0,000 ( $p<0,05)$ berarti fleksibilitas jaminan, kualitas pelayanan, dan kepatuhan syariah secara bersama-sama berpengaruh secara signifikan terhadap niat pengajuan pembiayaan mudharabah pada BMT
Nurul Jannah Gresik, sehingga dapat dikatakan HA diterima kebenarannya.

Uji Statistik $\mathbf{t}$

Tabel 7.

Pengambilan Keputusan dari Hasil Pengujian Hipotesis Pengaruh Parsial

\begin{tabular}{|l|c|l|}
\hline \multicolumn{1}{|c|}{ Variabel } & Signifikansi & \multicolumn{1}{|c|}{ Keterangan } \\
\hline $\begin{array}{l}\text { Fleksibilitas } \\
\text { Jaminan }\end{array}$ & $\begin{array}{c}0,000 \leq \\
0,05\end{array}$ & $\begin{array}{l}\text { Terdapat } \\
\text { pengaruh } \\
\text { signifikan secara } \\
\text { parsial }\end{array}$ \\
\hline $\begin{array}{l}\text { Kualitas } \\
\text { Pelayanan }\end{array}$ & $\begin{array}{c}0,014 \leq \\
0,05\end{array}$ & $\begin{array}{l}\text { Terdapat } \\
\text { pengaruh } \\
\text { signifikan secara } \\
\text { parsial }\end{array}$ \\
\hline $\begin{array}{l}\text { Kepatuhan } \\
\text { syariah }\end{array}$ & $\begin{array}{c}\text { Terdapat } \\
\text { pengaruh } \\
\text { signifikan secara } \\
\text { parsial }\end{array}$ \\
\hline
\end{tabular}

Sumber : Data olahan SPSS Statistics version 18

Berdasarkan perbandingan nilai signifikansi nilai t dengan 0,05 maka dapat disimpulkan bahwa variabel fleksibilitas jaminan, kualitas pelayanan, dan kepatuhan syariah secara parsial berpengaruh signifikan terhadap niat pengajuan pembiayaan mudharabah pada BMT Nurul Jannah Gresik.

\section{Variabel yang Mendeterminasi Niat Pengajuan Pembiayaan Mudharabah}

Variabel independen dengan nilai koefisien regresi terbesar merupakan variabel yang mampu mendeterminasi niat pengajuan pembiayaan mudharabah pada BMT Nurul Jannah Gresik. Hasil uji koefisien regresi dapat dilihat di Tabel 8.

Tabel 8.

Hasil Uji Regresi Linier Berganda

\begin{tabular}{|c|c|c|c|}
\hline \multirow{2}{*}{ Model } & \multicolumn{2}{|c|}{$\begin{array}{c}\text { Unstandardiz } \\
\text { ed } \\
\text { Coefficients }\end{array}$} & $\begin{array}{c}\text { Standardiz } \\
\text { ed } \\
\text { Coefficient } \\
\text { s }\end{array}$ \\
\cline { 2 - 4 } & B & Std. & Beta \\
\hline
\end{tabular}


Puspitasari, et al/Jurnal Ekonomi Syariah Teori dan Terapan Vol. 5 No. 1 Januari 2018: 1-16; DETERMINAN NIAT PENGAJUAN PEMBIAYAAN MUDHARABAH PADA BMT NURUL JANNAH GRESIK

\begin{tabular}{|l|l|c|c|c|}
\hline \multicolumn{2}{|c|}{} & & Error & \\
\hline \multicolumn{1}{|c|}{$\begin{array}{l}\text { Konstant } \\
\text { a }\end{array}$} & $-0,842$ & 0,370 & 0,361 \\
\hline $\begin{array}{l}\text { Fleksibilita } \\
\text { s } \\
\text { Jaminan }\end{array}$ & 0,328 & 0,070 & 0,210 \\
\cline { 2 - 4 } $\begin{array}{l}\text { Kualitas } \\
\text { Pelayana } \\
\text { n }\end{array}$ & 0,336 & 0,134 & 0,368 \\
\hline $\begin{array}{l}\text { Kepatuh } \\
\text { an } \\
\text { Syariah }\end{array}$ & 0,576 & 0,143 & 0,05 \\
\hline
\end{tabular}

Sumber : Data olahan SPSS Statistics version 18

Berdasarkan tabel di atas dapat diketahui bahwa variabel Kepatuhan Syariah merupakan variabel independen yang memiliki nilai koefisien regresi tertinggi. Hal ini menunjukkan bahwa Kepatuhan Syariah merupakan variabel yang paling berpengaruh atau paling menentukan niat pengajuan pembiayaan mudharabah pada BMT Nurul Jannah Gresik. Berdasarkan Tabel 8. dapat disusun persamaan atau model regresi dalam penelitian ini adalah sebagai berikut :

$Y=a+\beta_{1} X_{1}+\beta_{2} X_{2}+\beta_{3} X_{3}+e_{i}$

Niat Pengajuan Pembiayaan

Mudharabah =

$-0,842+0,328$ Fleksibilitas Jaminan $+0,336$

Kualitas Pelayanan $+0,576$ Kepatuhan

Syariah $+e_{i}$

Koefisien Determinasi

Tabel 9.

Koefisien Determinasi ( $R$ Square)

\begin{tabular}{|c|c|c|c|c|}
\hline Model & $\mathbf{R}$ & $\boldsymbol{R}$ Square & $\begin{array}{c}\text { Adjusted } \\
\boldsymbol{R} \text { Square }\end{array}$ & $\begin{array}{c}\text { Std. Error of } \\
\text { the Estimate }\end{array}$ \\
\hline 1 & 0,787 & 0,620 & 0,608 & 0,36004 \\
\hline
\end{tabular}

Sumber : Data olahan SPSS Statistics version 18

Berdasarkan Tabel 9. nilai $R$ Square adalah sebesar 0,620 atau $62 \%$. Nilai tersebut menunjukkan bahwa $38 \%$ variasi dari nilai niat pengajuan pembiayaan

mudharabah dapat dijelaskan oleh variabel independen dalam penelitian ini, sedangkan sisanya sebesar 38\% (100\% $62 \%)$ dijelaskan oleh variabel lain di luar model analisis.

\section{Pembahasan}

Pengaruh Fleksibilitas Jaminan, Kualitas Pelayanan, dan Kepatuhan Syariah secara Simultan terhadap Niat Pengajuan Pembiayaan Mudharabah

Hasil penelitian menunjukkan bahwa variabel fleksibilitas jaminan, kualitas pelayanan, dan kepatuhan syariah secara bersama-sama memiliki pengaruh signifikan terhadap niat pengajuan pembiayaan mudharabah. Hal tersebut dapat dilihat dari nilai $F$ hitung sebesar 50,532 dengan tingkat signifikansi uji $F$ hitung adalah sebesar 0,000. Angka tersebut lebih kecil dari 0,05 sehingga $\mathrm{H}_{0}$ ditolak, artinya bahwa fleksibilitas jaminan, kualitas pelayanan, dan kepatuhan syariah secara simultan berpengaruh signifikan terhadap niat pengajuan pembiayaan mudharabah pada BMT Nurul Jannah Gresik.

\section{Pengaruh Fleksibilitas Jaminan terhadap} Niat Pengajuan Pembiayaan Mudharabah pada BMT Nurul Jannah Gresik

Hasil penelitian menunjukkan bahwa variabel fleksibilitas jaminan memiliki pengaruh signifikan terhadap niat pengajuan pembiayaan mudharabah. Hal tersebut dapat dilihat dari hasil uji regresi linear dan uji- $\dagger$ pada variabel fleksibilitas jaminan $\left(X_{1}\right)$ yang menunjukkan nilai signifikansi sebesar 0,000 . Nilai signifikansi tersebut lebih kecil dari nilai 
Puspitasari, et al/Jurnal Ekonomi Syariah Teori dan Terapan Vol. 5 No. 1 Januari 2018: 1-16; DETERMINAN NIAT PENGAJUAN PEMBIAYAAN MUDHARABAH PADA BMT NURUL JANNAH GRESIK

signifikansi yang ditentukan yaitu 0,05.

Sehingga $\mathrm{H}_{0}$ ditolak dan HA diterima, artinya bahwa fleksibilitas jaminan berpengaruh signifikan terhadap niat pengajuan pembiayaan mudharabah pada BMT Nurul Jannah Gresik.

Fleksibilitas jaminan yang dimaksud dalam penelitian ini adalah fleksibilitas pemberian jaminan yang diberikan oleh calon mudharib baik yang bersifat fisik maupun non fisik kepada pengelola BMT Nurul Jannah Gresik untuk keperluan pembiayaan mudharabah. Kesetujuan responden terhadap pemberian alternatif atau pilihan dalam menentukan syarat pinjaman oleh BMT Nurul Jannah Gresik dapat mendorong niat untuk mengajukan pembiayaan mudharabah. Diterimanya hipotesis pertama juga menunjukkan bahwa kesetujuan masyarakat terhadap fleksibilitas jenis jaminan yang diberlakukan oleh BMT Nurul Jannah Gresik dapat mendorong keinginan calon nasabah untuk memperoleh biaya pengembangan usaha serta bersegera mengajukan pembiayaan modal usaha pada BMT Nurul Jannah Gresik.

Hasil penelitian menunjukkan bahwa fleksibilitas jaminan mempunyai pengaruh signifikan terhadap niat pengajuan pembiayaan mudharabah. Apabila jaminan yang diterapkan oleh BMT semakin fleksibel atau tidak menyulitkan calon mudharib, maka akan berpengaruh terhadap meningkatnya niat pengajuan pembiayaan mudharabah. Hasil penelitian ini sejalan dengan literatur yang ditulis oleh Yunus (2007) yang menyatakan bahwa penerapan pemberian kredit dengan fleksibilitas jaminan bahkan bebas agunan telah terbukti mampu mendorong bergeraknya sektor ekonomi riil dengan tingkat pengembalian kredit yang tinggi.

Pengaruh Kualitas Pelayanan terhadap Niat Pengajuan Pembiayaan Mudharabah pada BMT Nurul Jannah Gresik

Hasil penelitian menunjukkan bahwa variabel kualitas pelayanan memiliki pengaruh signifikan terhadap niat pengajuan pembiayaan mudharabah. Hal tersebut dapat dilihat dari hasil uji regresi linear dan uji- $\dagger$ pada variabel kualitas pelayanan $\left(X_{2}\right)$ yang menunjukkan nilai signifikansi sebesar 0,014. Nilai signifikansi tersebut lebih kecil dari nilai signifikansi yang ditentukan yaitu 0,05. Sehingga $\mathrm{H}_{0}$ ditolak dan HA diterima, artinya bahwa kualitas pelayanan berpengaruh signifikan terhadap niat pengajuan pembiayaan mudharabah pada BMT Nurul Jannah Gresik.

Hasil penelitian menunjukkan bahwa kualitas pelayanan mempunyai pengaruh signifikan terhadap niat pengajuan pembiayaan mudharabah. Apabila pelayanan BMT yang diterima atau dirasakan calon mudharib itu sesuai dengan apa yang diharapkan, maka kualitas pelayanan dipersepsikan baik dan memuaskan. Begitu pula sebaliknya. Dengan demikian baik buruknya kualitas pelayanan dari BMT tergantung kepada kemampuan penyedia layanan dalam memenuhi harapan masyarakat (para penerima layanan BMT) secara konsisten. Hasil penelitian ini sejalan dengan 
Puspitasari, et al/Jurnal Ekonomi Syariah Teori dan Terapan Vol. 5 No. 1 Januari 2018: 1-16; DETERMINAN NIAT PENGAJUAN PEMBIAYAAN MUDHARABAH PADA BMT NURUL JANNAH GRESIK

penelitian Arslan (2014) yang menujukkan

bahwa kualitas pelayanan berpengaruh

secara positif pada niat pembelian.

Pengaruh Kepatuhan Syariah terhadap Niat Pengajuan Pembiayaan Mudharabah pada BMT Nurul Jannah Gresik

Hasil penelitian menunjukkan bahwa variabel kepatuhan syariah memiliki pengaruh signifikan terhadap niat pengajuan pembiayaan mudharabah. Hal tersebut dapat dilihat dari hasil uji regresi linear dan uji- $\dagger$ pada variabel kepatuhan syariah $\left(X_{3}\right)$ yang menunjukkan nilai signifikansi sebesar 0,000. Nilai signifikansi tersebut lebih kecil dari nilai signifikansi yang ditentukan yaitu 0,05. Sehingga $\mathrm{H}_{0}$ ditolak dan HA diterima, artinya bahwa kepatuhan syariah berpengaruh signifikan terhadap niat pengajuan pembiayaan mudharabah pada BMT Nurul Jannah Gresik.

Prasetyo (2005:59) dalam Sutedi (2009:145) menjelaskan makna kepatuhan syariah adalah kepatuhan kepada fatwa DSN, karena fatwa DSN merupakan perwujudan prinsip dan aturan syariah yang harus ditaati dalam perbankan syariah maupun lembaga keuangan syari'ah non bank di Indonesia. Hasil penelitian ini menunjukkan bahwa akad peminjaman dana mudharabah dan budaya kerja yang sesuai dengan tuntunan syariah dapat mendorong keinginan nasabah untuk mengajukan pembiayaan modal usaha di BMT Nurul Jannah Gresik dalam waktu dekat. Usaha yang dibiayai oleh BMT Nurul Jannah Gresik sesuai dengan tuntunan syariah terkait erat dengan keinginan masyarakat untuk memperoleh biaya pengembangan usaha dari BMT Nurul Jannah Gresik. BMT Nurul Jannah Gresik memiliki sumber dana yang halal sesuai dengan tuntunan syariah dapat membuat masyarakat bersegera untuk mengajukan pembiayaan modal usaha pada BMT Nurul Jannah Gresik.

Hasil penelitian menunjukkan bahwa kepatuhan syariah mempunyai pengaruh signifikan terhadap niat pengajuan pembiayaan mudharabah. Kepercayaan dan keyakinan masyarakat pada BMT didasarkan dan dipertahankan melalui pelaksanaan prinsip hukum Islam yang diadaptasi dalam aturan operasional institusi tersebut. Tanpa adanya kepatuhan terhadap prinsip syariah, masyarakat akan kehilangan keistimewaan yang mereka cari sehingga akan berpengaruh pada keputusan mereka untuk memilih ataupun terus melanjutkan pemanfaatan jasa yang diberikan oleh BMT. Hasil penelitian ini sejalan dengan penelitian Murningsih dan Yunadi (2013) yang menunjukkan bahwa faktor syariah berpengaruh positif dan signifikan terhadap permintaan pembiayaan mudharabah.

Ketentuan terhadap kepatuhan syariah dijelaskan dalam firman Allah SWT surat AlJaatsiyah ayat 18.

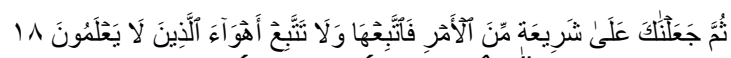
Øumma ja'alnÉka 'alÉ syarẾä̈immina'l-amri fattabi'hÉ walÉ tattabi' ahwÉ- Ñal-laİÊna lÉ ya'lamËn

Artinya : "Kemudian Kami jadikan kamu berada di atas suatu syariat (peraturan) 
Puspitasari, et al/Jurnal Ekonomi Syariah Teori dan Terapan Vol. 5 No. 1 Januari 2018: 1-16; DETERMINAN NIAT PENGAJUAN PEMBIAYAAN MUDHARABAH PADA BMT NURUL JANNAH

\section{GRESIK}

dari urusan (agama) itu, maka ikutilah syariat itu dan janganlah kamu ikuti hawa nafsu orang-orang yang tidak mengetahui." (QS 45:18, Departemen Agama Rl, 1998:817).

\section{SIMPULAN}

1. Berdasarkan hasil uji F statistik (secara simultan), menunjukkan bahwa secara statistik dapat disimpulkan bahwa fleksibilitas jaminan, kualitas pelayanan, dan kepatuhan syariah secara bersama-sama berpengaruh signifikan terhadap niat pengajuan pembiayaan mudharabah pada BMT Nurul Jannah Gresik.

2. Berdasarkan hasil uji $\dagger$ statistik (secara parsial) menunjukkan bahwa fleksibilitas jaminan berpengaruh signifikan terhadap niat pengajuan pembiayaan mudharabah pada BMT Nurul Jannah Gresik.

3. Berdasarkan hasil uji $\dagger$ statistik (secara parsial) menunjukkan bahwa kualitas pelayanan berpengaruh signifikan terhadap niat pengajuan pembiayaan mudharabah pada BMT Nurul Jannah Gresik.

4. Berdasarkan hasil uji † statistik (secara parsial) menunjukkan bahwa kepatuhan syariah berpengaruh signifikan terhadap niat pengajuan pembiayaan mudharabah pada BMT Nurul Jannah Gresik.

5. Kepatuhan syariah merupakan variabel yang paling berpengaruh atau paling menentukan niat pengajuan pembiayaan mudharabah pada BMT Nurul Jannah Gresik dengan nilai koefisien regresi sebesar 0,368.

\section{DAFTAR PUSTAKA}

Agag, Gooma \& El-Masry, Ahmed A. 2016. Understanding condumer intention to participate in online travel community and effects on consumer intention to purchase travel online and WOM: An integration of innovation diffusion theory and TAM with trust. Journal of Computers in Human Behavior, 60, 97-111.

An-Nawawi, Yahya bin Syarif. 2007. Syarah Arba'in Nawawi. Solo : Pustaka Arafah.

Arslan, Muhammad. 2014. Impact of Brand Image and Service Quality on Consumer Purchase Intention: A Study of Retail Store in Pakistan. Research on Humanities and Social Scienes. Vol. 4, no.22.

Awami, Shofia Nur. 2009. Peranan Lembaga Kevangan Mikro dan Kontribusi Kredit terhadap Pendapatan Kotor UKM Rumah Tangga setelah menjadi Kreditur (Studi Kasus BMT Muamalat). Jurnal Ilmu Pertanian. Vol 5, no.2.

Azra, Azyumardi. 2003. Berderma untuk Semua. Jakarta : PT. Mizan Pustaka.

Departemen Agama RI. 1998. Al-Qur'an dan Terjemahnya. Jakarta : AlHidayah Surabaya.

Fatwa DSN MUI No: 07/DSN-MUI/IV/2000 Tentang Pembiayaan Mudharabah (Qiradh).

Ghozali, Imam. 2012. Aplikasi Analisis Multivariate dengan Program IBM SPSS 20. Semarang: Badan Penerbit Universitas Diponegoro.

Huda, Nurul dan Mohamad Heykal. 2010. Lembaga Kevangan Islam : Tinjauan Teoritis dan Praktis. Jakarta : Kencana.

IImi, Makhalul. 2002. Teori dan Praktek lembaga Keuangan Mikro Syariah. Yogyakarta: Ull Press.

Kasmir. 2004. Manajemen Perbankan. Jakarta : PT. RAJA Grafindo Persada.

Mauludin, Hanif. 2004. Ananlisis Kualitas Pelayanan, Pengaruhnya Terhadap Image (Studi Pada Penderita RSUD DR.R. Koesma Tuban). Jurnal Penelitian Akuntansi, Bisnis, dan Manajemen. Vol. 7, no.l. Yogyakarta : Fakultas Syari'ah dan Hukum Universitas Islam Negeri Sunan Kalijaga. 
Puspitasari, et al/Jurnal Ekonomi Syariah Teori dan Terapan Vol. 5 No. 1 Januari 2018: 1-16;

DETERMINAN NIAT PENGAJUAN PEMBIAYAAN MUDHARABAH PADA BMT NURUL JANNAH

\section{GRESIK}

Noviandi, Barus Aulia. 2009. Analisis FaktorFaktor Pengambilan Pembiayaan dan Penilaian Efektifitas Pembiayaan Syariah Bagi Usaha Kecil pada BMT Dana Insani Kabupaten Gunung Kidul Propinsi Yogyakarta. Skripsi. Bogor : Fakultas Pertanian Institut Pertanian Bogor.

Oxford Advanced Leaner's Dictionary. 2005. Oxford: Oxford University Press.

Parasuraman, Zeithaml, dkk. 1990. Five Imperatives for Improving Servive Quality. Sloan Management Review.

Perwataatmadja, Karnaen Anwar dan Henri Samsul Bahri Tanjung. 2007. Bank Syariah (Teori, Praktik, dan Peranannya), Cet.l. Jakarta : Celestial Publising.

Puskopsyah. 2014. Lembaga Keuangan Mikro Syariah, (Online), http://www.puskopsyahbmtjateng.c om/. (Diakses tanggal 9 Juni 2016).

Ridwan, Muhammad. 2004. Manajemen Baitul Maal Wat Tamwil (BMT). Yogyakarta : UII Press.

Rosmalinda, Upia. 2015. Studi Kritik Prinsip Kehati-Hatian Dalam Perspektif Pencegahan Pembiayaan Bermasalah Pada Bank Syariah. Jurnal Universitas Muhammadiyah Metro. Vol 11, no.2.

Ruwati dan Pandi Afandi. 2014. Persepsi Nasabah Pada Aspek 5C Untuk Menentukan Kelayakan Pemberian Kredit Pada Nasabah PT BPR Nusamba Ampel Cabang Salatiga. Jurnal STIE Semarang. Vol 6, no.1: 5964.

Santoso, Singgih. 2011. Mastering SPSS Versi 19. Jakarta : PT Elex Media Komputindo.

Sheeran, Paschal. 2011. Intention-Behavior Relations: A Conceptual and Empirical Review. European Review of Social Psychology.

Sudarsono, Heri. 2003. Bank dan Lembaga Kevangan Syariah. Yogyakarta : Ekonisia.

Sutarno. 2004. Aspek-Aspek Hukum Perkreditan Pada Bank. Bandung : Alfabeta.

Sutedi, Andrian. 2009. Perbankan Syariah Tinjauan dan Beberapa Segi Hukum. Bogor : Ghalia Indonesia.
Ummah, Ghazirah Abdi. 2002. Fathul Baari syarah Shahih Al Bukhari. Jakarta: Pustaka Azzam.

White, Andrew. 2013. Singapura Apresiasi Kiprah BMT di Indonesia, (Online), http://www.republika.co.id/berita/e konomi/keuangan/13/10/26/mv8yxlsingapura-apresiasi-kiprah-bmt-diindonesia. (Diakses 4 Juni 2016).

Yunus, Muhammad. 2007. Bank Kaum Mikin. Tangerang Selatan : CV. Marjin Kiri. 